THE CRAFT OF CREATIVITY 
This page intentionally left blank 


\section{THE CRAFT}

OF

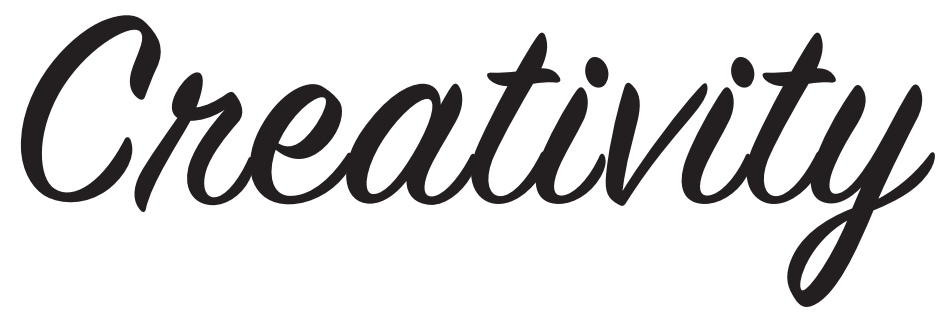

MATTHEW A. CRONIN

and JEFFREY LOEWENSTEIN

Stanford Business Books 
Stanford University Press

Stanford, California

()2018 by the Board of Trustees of the Leland Stanford Junior University. All rights reserved.

No part of this book may be reproduced or transmitted in any form or by any means, electronic or mechanical, including photocopying and recording, or in any information storage or retrieval system without the prior written permission of Stanford University Press.

Special discounts for bulk quantities of Stanford Business Books are available to corporations, professional associations, and other organizations. For details and discount information, contact the special sales department of Stanford University Press. Tel: (650) 725-0820, Fax: (650) 725-3457

Printed in the United States of America on acid-free, archival-quality paper Library of Congress Cataloging-in-Publication Data

Names: Cronin, Matthew A. (Professor of management), author. I Loewenstein, Jeffrey, author.

Title: The craft of creativity / Matthew A. Cronin and Jeffrey Loewenstein. Description: Stanford, California : Stanford Business Books, an imprint of Stanford University Press, 2018. I Includes bibliographical references and index.

Identifiers: LCCN 2017031231 I ISBN 9780804787376 (cloth : alk. paper) |

ISBN 9781503605077 (pbk. : alk. paper)

Subjects: LCSH: Creative ability. I Creative thinking. I Creative ability in business.

Classification: LCC BF408 .C7578 2018 I DDC 153.3/5—dc23

LC record available at https://lccn.loc.gov/2017031231

ISBN 9781503605510 (electronic)

Cover design: Matt Tanner

Typeset by Bruce Lundquist in 10/14 Minion 
For Hayes, who made it possible for me to start this work, and for Jason, who made it possible for me to complete it -Matt

For my craftiest creators, Jacki, Emma, and Alina 一Jeff 
This page intentionally left blank 